Article Review

\title{
Potensi Pangan Fermentasi Tempe Dalam Mengatasi Kejadian Stunting di Indonesia
}

\section{The Food Potential for Tempe Fermentation in Dealing with Stunting Events in Indonesia}

\author{
Fitri Fujiana $^{1 *}$, Vinka Theresia Pondaag ${ }^{2}$, Aurelia Afra ${ }^{2}$, Evy Fannia $^{2}$, Dzul Fadly ${ }^{2}$ \\ ${ }^{1}$ Program Studi Keperawatan, Universitas Tanjungpura, Pontianak, Indonesia \\ ${ }^{2}$ Program Studi Teknologi Pangan, Universitas Tanjungpura, Pontianak, Indonesia
}

(*fitri.fujiana@ners.untan.ac.id)

\begin{abstract}
ABSTRAK
Prevalensi kejadian stunting di Indonesia masih tinggi. Tingkat penurunan angka stunting cenderung fluktuatif dan belum memenuhi capaian target. Salah satu faktor yang mempengaruhi penurunan prevalensi stunting adalah asupan zat gizi yang dikonsumsi balita. Pemanfaatan sumber daya pangan lokal menjadi alternatif, salah satunya adalah pangan fermentasi tempe. Tempe merupakan makanan fermentasi dari kacang kedelai (Glicyne max) dengan bantuan mikroorganisme Rhizopus $s p$, yang saat ini mulai dikembangkan dengan memanfaatkan jenis bahan baku lainnya. Review ini dilakukan untuk memahami potensi pangan lokal fermentasi tempe terkait dengan upaya penurunan angka stunting di Indonesia. Telah banyak dilakukan pengembangan pangan fermentasi tempe selain dari kacang kedelai. Proses fermentasi tersebut cenderung meningkatkan zat gizi makro dan mikro pangan yang dibutuhkan oleh tubuh untuk menunjang pertumbuhan yang optimal sehingga pada akhirnya mampu mencegah stunting.
\end{abstract}

Kata kunci : Fermentasi, Stunting, Tempe

\begin{abstract}
The prevalence of stunting in Indonesia is still high. The rate of declinefigures of stunting tend to fluctuate and do not meet the target achievement. One of the factors that influence the reduction in the prevalence of stunting is the intake of nutrients consumed by children under five. Utilization of local food resources is an alternative, one of which is the use of fermented tempe food. Tempe is a fermented food made from soybeans (Glicyne max) with the help of the microorganism Rhizopus sp, which is currently being developed by utilizing other types of raw materials. This review was conducted to understand the potential of local food fermented tempeh related to efforts to reducerates stunting in Indonesia. There have been many developments in tempe fermented food apart from soybeans. The fermentation process tends to increase the macro and micro nutrients needed by the body to support optimal growth so that in the end it can prevent stunting.
\end{abstract}

Keywords : Fermentation, Stunting, Tempeh

https://doi.org/10.33860/jik.v15i2.481

(C) 2021 by the authors. Submitted for possible open access publication under the terms and conditions of the Creative

Commons Attribution (CC BY SA) license (https://creativecommons.org/licenses/by-sa/4.0/). 


\section{PENDAHULUAN}

Secara global, 162 juta balita mengalami stunting pada tahun 2012. Angka tersebut sudah menurun dari angka awal sebesar 197 juta di tahun 2000. Hasil data menunjukkan sebagian besar penderita stunting berada di wilayah Asia $^{(1)}$. Penurunan dan peningkatan prevalensi stunting yang ada di Indonesia telah dijabarkan oleh Data Riset Kesehatan Dasar tahun 2018. Teori menyatakan bahwa penyebab dari penurunan prevalensi stunting diakibatkan oleh kurangnya konsumsi asupan gizi pada balita, penyakit tertentu yang belum sembuh atau infeksi yang cukup lama ${ }^{(2)}$.

Stunting merupakan penghambatan pertumbuhan yang dialami oleh individu yang mengakibatkan kondisi tidak normal dan berdampak pada penurunan produktivitas dan imunitas, serta memiliki tubuh yang lebih pendek dibandingkan tubuh normal ${ }^{(3)}$. Faktor penyebab kejadian stunting secara tidak langsung meliputi gizi buruk, kurangnya pengetahuan ibu, ketersediaan pangan, pola asuh, pelayanan kesehatan, buruknya sanitasi, dan lain-lain. Faktor tidak langsung memiliki keterkaitan dan bersumber pada akar dari masalah pendidikan dan ekonomi keluarga. Faktor lain yang berpotensi dalam menyebabkan risiko terjadinya stunting, seperti pernikahan usia dini, frekuensi kunjungan posyandu, dan riwayat kenaikan berat badan ${ }^{(4)}$. Asupan gizi merupakan faktor penting dalam menentukan kualitas manusia sejak masih berada dalam janin. Pemberian asupan gizi yang dari segi jenis dan jumlah sangatlah mempengaruhi pertumbuhan anak. Zat gizi berupa protein dan mineral merupakan asupan gizi yang sangat berpengaruh pada pertumbuhan anak ${ }^{(5)}$.

Proses pengolahan bahan makanan dengan memanfaatkan mikroorganisme dikenal sebagai fermentasi. Makanan fermentasi sudah dikenal sejak jaman kuno untuk pengawetan, meningkatkan cita rasa, dan menghasilkan produk baru. Proses fermentasi dapat meningkatkan nilai tambah produk hasil fermentasi dibandingkan dengan bahan bakunya. Peningkatan nilai tambah ini antara lain mencakup aspek nilai jual, pengawetan bahan makanan, nilai nutrisi, cita rasa dan untuk pengembangan produk baru ${ }^{(6)}$. Tempe kedelai merupakan produk berbentuk padatan kompak berwarna putih, yang diperoleh dari kedelai kupas yang sudah direbus dan difermentasi menggunakan Rhizopus spp ${ }^{(7)}$. Kandungan gizi yang tinggi seperti protein, lemak, karbohidrat, dan vitamin bisa didapatkan dari tempe.

Kejadian stunting sangat penting dicegah. Salah satu caranya dengan mengonsumsi pangan fermentasi yang bergizi tinggi seperti tempe. Tujuan dari review ini adalah mengidentifikasi kandungan gizi pangan fermentasi tempe dari berbagai jenis bahan baku di Indonesia dalam mengatasi permasalahan stunting.

\section{METODE PENELITIAN}

Pada kajian ini, dilakukan observasi terhadap literatur-literatur terkait yang terpublikasi secara daring melalui situs-situs, seperti Google Scholar, Science Direct, Scopus. Proses memperoleh literatur-literatur terkait dilakukan dengan mencari kata kunci "tempe" dan "stunting". Pengumpulan data dilakukan selama dua bulan dan daring. Pada penelitian ini, tidak dilakukan pembatasan terhadap tahun terbit literatur. Terdapat 21 sumber ilmiah yang diterbitkan dalam jangka waktu 1977 - 2020, dengan spesifikasi bahwa literatur tersebut harus dapat diakses secara menyeluruh dan lengkap.

\section{HASIL DAN PEMBAHASAN}

Keterlambatan pertumbuhan fisik masih menjadi permasalahan anak-anak di seluruh dunia. Faktanya, 30\% anak di negara berkembang mengalami stunting. Kurang memperhatikan kebutuhan gizi anak hingga seorang anak berusia dua tahun karena perkembangan selama periode ini berdampak pada seorang anak. Stunting selama periode ini terkait dengan hasil yang buruk di bidang kesehatan, perkembangan kognitif, dan pencapaian pendidikan dan ekonomi di kemudian hari ${ }^{(8)}$.

Stunting diakibatkan oleh beberapa faktor resiko seperti kelahiran prematur sebagai faktor risiko utama, sanitasi yang tidak layak merupakan faktor lingkungan yang mengikutinya, gizi ibu dan anak serta risiko infeksi ${ }^{(8)}$. Pemberian ASI yang kurang optimal pada 1.000 hari pertama kehidupan, pola makan yang buruk dan tidak seimbang, asupan vitamin dan juga mikronutrien juga beresiko ${ }^{(9)}$. Potensi yang terjadi berupa rentannya tubuh terpapar infeksi dan gangguan perkembangan otak anak $^{(10)(11)}$. Pada negara berkembang stunting 
dapat dicegah apabila faktor risiko dapat dihilangkan. Pencegahan dan pengelolaan infeksi masa kanak-kanak dan meningkatkan gizi di banyak negara berkembang dapat dilakukan sebagai langkah mengatasi stunting $^{(12)}$. Pencegahan tersebut dilakukan dengan fokus pada intervensi pra dan pasca kehamilan, memperbaiki lingkungan tempat tinggal, peningkatan sanitasi, melakukan diagnosis dan mengobati infeksi ibu dan anak juga dapat mengatasi efek malgizi antargenerasi ${ }^{(13)}$.

\section{Gizi terhadap Stunting}

Status gizi merupakan bentuk variabel tertentu yang menunjukkan realisasi keadaan gizi seseorang. Gizi dapat menyediakan energi, membangun dan memelihara jaringan tubuh serta mengatur proses kehidupan pada tubuh ${ }^{(14)}$. Kebutuhan gizi anak dengan masalah kesehatan seperti stunting berbeda dengan anak normal pada umumnya.

Konsumsi protein asal hewani pada anak stunting signifikan lebih rendah dibandingkan anak tidak stunting. Mengonsumsi susu dapat membantu menyumbangkan protein sebesar 7,67 g/hari pada anak stunting dan 16,73 g/hari pada anak tidak stunting. Sebagian besar anak berumur 3-5 tahun memerlukan asupan zat gizi seimbang baik dari segi jumlah, maupun kualitas. Pada usia tersebut penerapan pola makan keluarga dengan porsi setengah dari orang dewasa sudah mulai dijalani. Hal tersebut perlu diperhatikan karena ketika usia 3 tahun, permasalahan sulit makan mulai muncul yang berdampak pada penghambatan pertumbuhan ${ }^{(15)}$.

\section{Produk Pangan Fermentasi Tempe}

Proses pengolahan bahan makanan dengan memanfaatkan mikroorganisme dikenal sebagai fermentasi ${ }^{(6)}$. Proses fermentasi digunakan sebagai upaya dalam menjaga kualitas dan keamanan makanan, mulai dari memperpanjang umur simpan, mengurangi volume, meningkatkan flavor, mempendek waktu memasak, menyediakan ketersediaan gizi yang lebih baik, hingga dianggap sebagai makanan fungsional yang baik bagi kesehatan ${ }^{(16)}$. Tempe merupakan produk fermentasi populer di Indonesia dan sudah ada sejak tahun 1600-an. Sebagai salah satu produk fermentasi asal kacang-kacangan, tempe umumnya menggunakan kacang kedelai sebagai substratnya. Adapun jenis produk fermentasi tempe yang dikembangkan di Indonesia dapat dilihat pada Tabel 1.

Tabel 1. Daftar Jenis Produk Fermentasi Tempe

\begin{tabular}{|c|c|c|c|}
\hline Jenis Tempe & Bahan Baku & $\begin{array}{l}\text { Nama Ilmiah } \text { Bahan } \\
\text { Baku }\end{array}$ & Referensi \\
\hline Tempe kedelai & Kacang kedelai & Glicyne max & $\begin{array}{l}\text { Mukhoyaroh, } 2015^{(17)} \text {; Chalid et } \\
\text { al.2019(18); Kim et.al, } 2006^{(19)} \text {; } \\
\text { Liem et al. } 1977^{(20)}\end{array}$ \\
\hline Tempe gude & Kacang gude & Cajanus cajan $\mathrm{L}$. & Sine at al. $2018^{(21)}$ \\
\hline Tempe gembus & Kacang kedelai & Glicyne $\max$ & $\begin{array}{l}\text { Afifah, et al. } 2014^{(22)} \text {; Afifah et } \\
\text { al. } 2020^{(23)}\end{array}$ \\
\hline Tempe biji lamtoro & Biji lamtoro & Leucaena leucocephala & Ishartani et al. $2019^{(24)}$ \\
\hline Tempe biji lamun & Biji lamun & $\begin{array}{l}\text { Lamun thalassodendron } \\
\text { ciliatum }\end{array}$ & Kole et al. $2020^{(25)}$ \\
\hline $\begin{array}{l}\text { Tempe } \\
\text { bekatul }\end{array}$ & Bekatul beras & Oryza sativa & Cempaka et al. 2018 \\
\hline Tempe benguk & Kacang kara & $\begin{array}{l}\text { Mucuna prurience L.D.C } \\
\text { var. utilis }\end{array}$ & Handajani, 2001 ${ }^{(27)}$ \\
\hline Tempe lupin & Kacang lupin & $\begin{array}{l}\text { L. angustifolius } \mathrm{cv} \text {. } \\
\text { Gunguru }\end{array}$ & Fudiyansyah, 1995(28) \\
\hline Tempe biji nangka & Biji nangka & Artocarpus heterophyllus & $\begin{array}{l}\text { Andaka et al. } 2015^{(29)} \text {; Irna A et } \\
\text { al. } 2020^{(30)}\end{array}$ \\
\hline Tempe biji karet & Biji karet & Havea brasiliensis & Kusnanto et al., 2013(31) \\
\hline $\begin{array}{l}\text { Tempe } \\
\text { kacang hijau }\end{array}$ & Kacang hijau & Vigna radiata $\mathrm{L}$. & Maryam S, 2015(32) \\
\hline Tempe biji durian & Biji durian & Durio zibethinus & $\begin{array}{l}\text { Sawitri dan Santoso, 2014(33); } \\
\text { Maharani et al. } 2016^{(34)}\end{array}$ \\
\hline Tempe biji ketapang & biji ketapang & Terminalia cattapa & $\begin{array}{l}\text { Lelatobur LE dan Dewi L, } \\
2016^{(35)}\end{array}$ \\
\hline
\end{tabular}




\section{Zat Gizi Pangan Fermentasi Tempe}

Produk hasil fermentasi jika dibandingkan dengan bahan baku sendiri memiliki keunggulan ditinjau dari segi gizi, nutrasetikal dan manfaat untuk kesehatan. Hal ini dapat dipengaruhi oleh aktivitas mikroorganisme yang dapat meningkatkan kualitas produk, sebagai contoh: kapang Rhizopus ternyata bersifat simbiose dengan bakteri pembentuk vitamin B-12 (20). Tempe mengandung 157 $\mathrm{kal} / 100 \mathrm{~g}$, protein $(12,7 \%)$, karbohidrat dan lemak (4\%), vitamin B1 $(0,17 \mathrm{mg})$ dan vitamin B12 $(2.9 \mu \mathrm{g})$, rendah kolesterol dan lemak jenuh, berserat tinggi, dan protein $(19,5 \%)$ yang sebanding dengan protein produk daging. Adanya proses fermentasi menyebabkan kadar protein pada tempe meningkat. Pada hasil fermentasi kacang lamtoro yang dijadikan kecap terdapat kadar protein yang cukup tinggi pada biji $(107,44 \mathrm{mg} / \mathrm{g})$, koji $(86,1 \mathrm{mg} / \mathrm{g})$ dan moromi $(208,56 \mathrm{mg} / \mathrm{g})^{(36)}$.

\section{Keunggulan Pangan Fermentasi}

Makanan lebih mudah dicerna oleh tubuh setelah proses fermentasi karena adanya aktivitas mikroba yang menguraikan kandungan gizi menjadi lebih sederhana. Pada fermentasi tempe gude (Cajanus cajan L.) terjadi perubahan kadar nilai gizi seperti vitamin dan mineral akibat hidrolisis senyawa kompleks biji gude. Aktivitas kapang membuat kadar abu, nitrogen, besi, kalsium, fosfor mengalami penurunan, sedangkan vitamin B12 meningkat sebesar $16,56 \%$ dibandingkan dengan biji gude sebelum fermentasi ${ }^{(21)}$. Hal serupa terjadi pada tape onggok yang mengalami proses fermentasi 0-3 hari mengalami peningkatan kadar glukosa dari 2,19-3,83 g\%. Karbohidrat (pati) pada tape onggok telah bereaksi dengan enzim atau terhidrolisis sehingga menghasilkan glukosa.

Bekatul yang mengalami proses fermentasi mengalami perubahan pada kadar lemak dan karbohidrat yang menurun, namun meningkat untuk kadar abu, protein, dan serat pangannya. Hal tersebut dapat terjadi akibat kandungan yang ada pada bekatul diambil oleh kapang sebagai gizi untuk pertumbuhannya ${ }^{(37)}$.
Peningkatan kadar protein pada perlakuan 4-6 minggu akibat penguraian molekul protein kompleks menjadi asam amino selama proses fermentasi kecap ampas tahu. Waktu yang semakin lama membuat enzim protease yang dihasilkan oleh bakteri halotoleran pada proses fermentasi dapat lebih banyak melakukan pemecahan protein Kandungan protein merupakan refleksi dari jumlah massa sel yang dipengaruhi oleh jumlah massa mikroba yang juga meningkat. Peningkatan jumlah massa mikroba selama proses fermentasi dapat diindikasikan sebagai peningkatan kadar protein hasil analisis ${ }^{(38)}$.

\section{Keamanan Makanan Fermentasi}

Pada umumya makanan fermentasi cukup aman untuk dikonsumsi terutama makanan fermentasi tradisional. Tingkat keracunan akibat makanan fermentasi jarang sekali kita dengar. Kasus yang sering terdengar yaitu keracunan tempe bongkrek. Terjadinya keracunan pada tempe bongkrek disebabkan oleh adanya bakteri Pseudomonas cocovenans dan pertumbuhan kapang Rhizopus oligosporus tidak optimal sebagai akibat proses preparasi bahan baku yang kurang baik. Di samping itu, pada oncom juga dapat membantuk senyawa racun aflatoksin (tipe B1) yang dihasilkan oleh Aspergillus flavus, khususnya bila bahan baku yang digunakan berasal dari bungkil kacang ${ }^{(39)}$. Potensi Pangan Fermentasi Tempe dari berbagai Jenis Bahan Baku dalam Pencegahan Stunting

Faktor langsung kejadian stunting adalah pemenuhan zat gizi terutama asupan energi dari zat gizi makro (karbohidrat, lemak dan protein). Selain disebabkan oleh defisiensi zat gizi makro, Stunting juga berhubungan dengan kekurangan Seng (Zn). Rendahnya sintesis hormon pertumbuhan dapat menghambat pertumbuhan linier dan dapat menyebabkan kondisi stunting pada masa balita ${ }^{(40)}$. Stunting dapat diatasi dengan memenuhi kebutuhan gizi anak berupa zat gizi makro dan mikro disertakan pola asuh yang baik. Potensi pangan fermentasi sebagai bahan pangan bergizi disajikan pada Tabel 2.

Tabel 2. Potensi Pangan Fermentasi Tempe Dari Berbagai Jenis Bahan Baku

\begin{tabular}{llll}
\hline Referensi & Bahan & Zat Gizi Terukur & Manfaat \\
\hline (Sine, 2018) $^{(21)}$ & Gude (Cajanus cajan) & Nitrogen, vit B12, Fe, Ca, P & Meningkatkan gizi \\
\hline (Mukhoyaroh, 2015) $^{(17)}$ & Kedelai (Glycine max) & Protein & Mengatasi kurang gizi \\
\hline (Afifah et al., 2014) $^{(2)}$ & $\begin{array}{l}\text { Kedelai /ampas tahu } \\
\text { (Glycine max) }\end{array}$ & Protein & $\begin{array}{l}\text { Mencegah penyakit } \\
\text { kardiovaskuler }\end{array}$ \\
\hline
\end{tabular}




\begin{tabular}{|c|c|c|c|}
\hline Referensi & Bahan & Zat Gizi Terukur & Manfaat \\
\hline (Afifah et al., 2020) & Kedelai (Glycine max) & $\begin{array}{l}\text { Protein, lemak, serat, } \\
\text { isoflavon, antioksidan }\end{array}$ & $\begin{array}{l}\text { Meningkatkan gizi } \\
\text { dan aktivitas } \\
\text { antioksidan. }\end{array}$ \\
\hline (Kole et al., 2020) ${ }^{(25)}$ & $\begin{array}{l}\text { Biji } \\
\text { Lamun (Enhalus } \\
\text { acoroides) }\end{array}$ & Karbohidrat, lemak & Tinggi nilai gizi \\
\hline$(\text { Cempaka et al., 2018) })^{(26)}$ & Bekatul (Oryza sativa) & $\begin{array}{l}\text { Protein, lemak, total fenolik, } \\
\text { probiotik }\end{array}$ & $\begin{array}{l}\text { Kesehatan, diet dan } \\
\text { sebagai pengganti } \\
\text { daging. }\end{array}$ \\
\hline$(\text { Chalid, 2019) })^{(18)}$ & Kedelai (Glycine max) & Protein, lemak & $\begin{array}{l}\text { antihipertensi, anti- } \\
\text { bacterial agent. }\end{array}$ \\
\hline $\begin{array}{l}\text { (Fudiyansyah et al., } \\
2007)^{(28)}\end{array}$ & Lupin (lupinus albus) & Protein, $\mathrm{P}, \mathrm{Ca}, \mathrm{S}, \mathrm{K}$ & Meningkatkan gizi \\
\hline (Handajani, 2001) $^{(27)}$ & $\begin{array}{l}\text { Koro benguk (Mucuna } \\
\text { pruriens) }\end{array}$ & $\begin{array}{l}\text { Protein, lemak, karbohidrat, } \\
\text { serat, mineral, vit E, } \\
\text { isoflavon }\end{array}$ & $\begin{array}{l}\text { Kesehatan, senyawa } \\
\text { bioaktif }\end{array}$ \\
\hline (Ishartani et al., 2019) & $\begin{array}{l}\text { Lamtoro (Leucaena } \\
\text { leucocephala) }\end{array}$ & Protein, lemak, asam amino & $\begin{array}{l}\text { Meningkatkan umur } \\
\text { simpan }\end{array}$ \\
\hline$(\text { Irna et al., 2020) })^{(30)}$ & $\begin{array}{l}\text { Biji } \\
\text { Nangka (Leucaena } \\
\text { leucocephala) }\end{array}$ & $\begin{array}{l}\text { Karbohidrat, protein, lemak, } \\
\mathrm{P}, \mathrm{Ca}, \mathrm{Fe}\end{array}$ & Meningkatkan gizi \\
\hline (Kusnanto et al., 2013) $^{(31)}$ & $\begin{array}{l}\text { Biji karet (Hevea } \\
\text { brasiliensis) }\end{array}$ & Protein, $\mathrm{HCN}$ & Pangan tinggi protein \\
\hline$($ Andaka et al., 2015) & $\begin{array}{l}\text { Biji Nangka (Leucaena } \\
\text { leucocephala) }\end{array}$ & Protein, serat pangan & $\begin{array}{l}\text { Kandungan gizi yang } \\
\text { baik }\end{array}$ \\
\hline $\begin{array}{l}\text { (Sawitri }_{2014)^{(33)}} \quad \& \quad \text { Santoso, } \\
\end{array}$ & $\begin{array}{l}\text { Biji durian (Durio } \\
\text { zibethinus) }\end{array}$ & Protein & $\begin{array}{l}\text { Kandungan gizi yang } \\
\text { baik }\end{array}$ \\
\hline (Maharani et al., 2016) $^{(34)}$ & $\begin{array}{l}\text { Biji durian (Durio } \\
\text { zibethinus) }\end{array}$ & Protein & $\begin{array}{l}\text { Pangan masa depan, } \\
\text { meningkatkan gizi }\end{array}$ \\
\hline $\begin{array}{l}(\text { Liem } \\
1977)^{(20)}\end{array}$ & Kedelai (Glycine max) & Vit B12 & $\begin{array}{l}\text { Membentuk } \\
\text { eritrosit dan } \\
\text { mencegah anemia }\end{array}$ \\
\hline$\left(\right.$ Maryam, 2015) ${ }^{(32)}$ & $\begin{array}{l}\text { Kacang hijau (Vigna } \\
\text { radiata) }\end{array}$ & Antioksidan (vit E) & $\begin{array}{l}\text { Menangkal radikal } \\
\text { bebas }\end{array}$ \\
\hline (Mursyid et al., 2018) $^{(41)}$ & Kedelai (Glycine max) & Protein, lemak, karbohidrat & Meningkatkan gizi \\
\hline (Hashim et al., 2018) $^{(42)}$ & $\begin{array}{l}\text { Kedelai dengan bungkus } \\
\text { daun pisang (Glycine max) }\end{array}$ & Total fenol, antioksidan & $\begin{array}{l}\text { Tinggi komponen } \\
\text { bioaktif }\end{array}$ \\
\hline$(\text { Kim et al., 2006) })^{(19)}$ & Kedelai(Glycine max) & Protein & Tinggi zat gizi \\
\hline $\begin{array}{l}\text { (Keuth \& Bisping, } \\
1994)^{(43)}\end{array}$ & Kedelai (Glycine max) & Vit B12 & Membentuk otot \\
\hline
\end{tabular}

Proses fermentasi dengan teknologi yang sesuai dapat menghasilkan produk protein $^{(44)}$. Sebagai salah satu sumber gizi yang kaya akan protein nabati yang mudah dicerna, tempe dapat dimanfaatkan sebagai pangan pembangun dan pemelihara sel-sel tubuh yang rusak, serta dapat digunakan untuk menambah berat badan khususnya kelompok balita ${ }^{(40)(45)}$.

\section{KESIMPULAN DAN SARAN}

Proses pengolahan fermentasi tempe dapat meningkatkan zat gizi yang terkandung baik makro maupun mikro yang dibutuhkan oleh tubuh, dengan demikian jenis pangan ini berpotensi sebagai bahan pangan penunjang pertumbuhan sehingga dapat mencegah kejadian stunting.

Penelitian ini hanya berupa studi literasi tentang pengolahan fermentasi tempe. Diharapkan penelitian lebih lanjut mengenai zat gizi tempe lebih detail yang berpengaruh bagi tubuh.

\section{DAFTAR PUSTAKA}

1. UNICEF/WHO/World Bank. Child Malnutrition Database: Estimates for 2012 and Launch of Interactive Data Dashboards [Internet]. Janewa: World Health Organization; 2012 p. 1-3. Available from: https://www.who.int/nutgrowthdb/jme_2012_ summary_note_v2.pdf 
2. Ahmadi F, Triwinarto A. Analysis descriptive stunting in Indonesia Health Research Basic. Annals of Tropical Medicine and Public Health. 2019;22(11):472-7.

3. Hoddinott J, Behrman JR, Maluccio JA, Melgar P, Quisumbing AR, Ramirez-Zea M, et al. Adult consequences of growth failure in early childhood. The American Journal of Clinical Nutrition. 2013 Nov 1;98(5):1170-8.

4. Yuniarti K. Hubungan Usia Menikah Remaja dengan Kategori Stunting. Jurnal Darul Azhar. 2020;9(1): 40-48.

5. Mardewi KW. Kadar Seng Serum Rendah sebagai Faktor Risiko Perawakan Pendek pada Anak [Tesis]. Universitas Udayana Denpasar. 2014.

6. Pawiroharsono S. Potensi Pengembangan Industri dan Bioekonomi Berbasis Makanan Fermentasi Tradisional. Jurnal Ilmu Kefarmasian Indonesia. 2007;5(2): 85-91.

7. BSN. SNI 3144: 2015. Tenpe Kedelai. Badan Standarisasi Nasional. Jakarta; 2015.

8. Danaei G, Andrews KG, Sudfeld CR, Fink G, McCoy DC, Peet E, et al. Risk Factors for Childhood Stunting in 137 Developing Countries: A Comparative Risk Assessment Analysis at Global, Regional, and Country Levels. PLoS Med. 2016; 13(11):1-18.

9. Vonaesch P, Tondeur L, Breurec S, Bata P, Nguyen LBL, Frank T, et al. Factors associated with stunting in healthy children aged 5 years and less living in Bangui (RCA). Wieringa $\mathrm{F}$, editor. PLoS ONE. 2017 Aug 10;12(8): 1-17.

10. Adair LS. Developing World Perspective: The Importance of Growth for Short-Term Health. Nestlé Nutr Inst Workshop Ser. 2010;78(13): 111-120.

11. Prendergast AJ, Humphrey JH. The stunting syndrome in developing countries. Paediatrics and International Child Health. 2014; 34(4): 250-265

12. Arifeen SE, Hoque DE, Akter T, Rahman M, Hoque ME, Begum K, et al. Effect of the Integrated Management of Childhood Illness strategy on childhood mortality and nutrition in a rural area in Bangladesh: a cluster randomised trial. Lancet 2009; 374(11): 393403.

13. Stein A, Rebecca MP, Sherryl HG, Elizabeth R, Atif R, Meaghan MC, Louise MH, Carmine MP. Effects of perinatal mental disorders on the fetus and child. Lancet. 2014;384(20): 1800-1819.

14. Amirullah A, Putra ATA. Deskripsi Status Gizi Anak Usia 3 Sampai 5 Tahun Pada Masa Covid 19. MURHUM : Jurnal Pendidikan Anak Usia Dini. 2020; 19(12): 16-27.

15. Sari EM, Juffrie M, Nurani N, Sitaresmi MN. Asupan protein, kalsium dan fosfor pada anak stunting dan tidak stunting usia 24-59 bulan.
Jurnal Gizi Klinik Indonesia. 2016 Apr 30;12(4):152.

16. Sharma A, Kapoor AC. Levels of antinutritional factors in pearl millet as affected by processing treatments and various types of fermentation. Plant Food Hum Nutr. 1996 Apr;49(3):241-52.

17. Mukhoyaroh H. Pengaruh Jenis Kedelai, Waktu dan Suhu Pemeraman terhadap Kandungan Protein Tempe Kedelai. florea [Internet]. 2015; 2(2): 47-51.

18. Chalid SY. Angiotensin Converting Enzyme Inhibitor Activity of the Soybean Tempeh Protein as Functional food. International Journal of GEOMATE. 2019; 16(56): 73-78.

19. Kim S-B, Lee D-W, Cheigh C-I, Choe E-A, Lee S-J, Hong Y-H, et al. Purification and characterization of a fibrinolytic subtilisin-like protease of Bacillus subtilis TP-6 from an Indonesian fermented soybean, Tempeh. Journal of Industrial Microbiology \& Biotechnology. 2006 Jun;33(6):436-44.

20. Liem ITH, Steinkraus KH. Production of Vitamin B-12 in Tempeh, a Fermented Soybean Foodt. Appl Environ Microbiol. 1977; 34(6): 773-776.

21. Sine Y. Perubahan Kadar Vitamin dan Mineral pada Fermentasi Tempe Gude (Cajanus cajan L.). JSLK : Jurnal Saintek Lahan Kering. 2018; $1(1): 1-3$

22. Afifah DN, Sulchan M, Syah D, Yanti Y, Suhartono MT, Kim JH. Purification and Characterization of a Fibrinolytic Enzyme from Bacillus pumilus 2.g Isolated from Gembus, an Indonesian Fermented Food. Preventive Nutrition and Food Science. 2014 Sep 30;19(3):213-9.

23. Afifah DN, Nabilah N, Supraba GT, Pratiwi SN, Nuryanto, Sulchan M. The Effects of Tempeh Gembus, an Indonesian Fermented Food, on Lipid Profiles in Women with Hyperlipidemia. Current Nutrition \& Food Science. 2020 Jan 13;16(1):56-64.

24. Ishartani D, Istiqomah NA, Nurisiwi A, Sari AM. Proximate and Amino Acids Composition of Powdered Over Fermented Mlanding Tempeh. IOP Conf Ser: Earth Environ Sci. 2019 Nov 5;379:012007.

25. Kole H, Tuapattinaya P, Watuguly T. Analisis Kadar Karbohidrat dan Lemak pada Tempe Berbahan Dasar Biji Lamun (Enhalus acoroides). BIOPENDIX: Jurnal Biologi, Pendidikan dan Terapan. 2020 Apr 30;6(2):916.

26. Cempaka L, Eliza N, Ardiansyah A, Handoko DD, Astuti RM. Proximate Composition, Total Phenolic Content, and Sensory Analysis of Rice Bran Tempeh. Makara Journal of Science. 2018;22(2):89-94.

27. Handajani S. Indigenous mucuna tempe as 
functional food. Asia Pac J Clin Nutr. 2001 Sep 27;10(3):222-5.

28. Fudiyansyah N, Petterson DS, Bell RR, Fairbrother AH. A nutritional, chemical and sensory evaluation of lupin (L. angustifolius) tempe. International Journal of Food Science \& Technology. 2007 Jul 1;30(3):297-305.

29. Andaka G, Nareswary PO, Budilaksana F, Trishadi DE. Pemanfaatan Limbah Biji Nangka sebagai Bahan Alternatif dalam Pembuatan Tempe. Prosiding Seminar Nasional ReTII Ke14. Publikasi Karya Ilmiah Institut Teknologi Nasional. Yogyakarta. 2015.

30. Irna A, Marlena D, Ariyani D, Marfhadella P, Saputri R, Latipah N. Pengaruh Durasi Fermentasi dan Jumlah Ragi Terhadap Kualitas Tempe Biji Nangka. ISEJ: Indonesian Science Education Journal. 2020;1(1):35-41.

31. Kusnanto F, Susanto A, Mulyani H. Pengaruh Waktu Fermentasi terhadap Kadar Protein dan Daya Terima Tempe dari Biji Karet (Hevea Brasiliensis) sebagai Sumber Belajar Biologi SMA pada Materi Bioteknologi Pangan. BIOEDUKASI (Jurnal Pendidikan Biologi). 2013; 4(1). 1-7.

32. Maryam S. Potensi Tempe Kacang Hijau (Vigna Radiata L) Hasil Fermentasi Menggunakan Inokulum Tradisional Sebagai Pangan Fungsional. Jurnal Sains dan Teknologi. 2015;4(2):635-641.

33. Sawitri A, Santoso H. Pengaruh Waktu Fermentasi Terhadap Kadar Protein Tempe Biji Durian (Durio zibethinus) Sebagai Sumber Belajar Biologi SMA Kelas XII Pada Materi Bioteknologi Pangan. BIOEDUKASI Jurnal Pendidikan Biologi Universitas Muhammadiyah Metro. 2014;5(2):131-140.

34. Maharani AY, Hidayati NR, Handayani S, Astuti DE, Nopida R, Fachrurazi S. Pengaruh Lama Fermentasi terhadap Kadar Protein Tempe Biji Durian. Florea. 2016;3(2): 45-48.

35. Lelatobur LE, Dewi L. Optimasi Perebusan Biji Ketapang (Terminalia cattapa) Dalam Fermentasi Tempe [Skripsi]. [Salatiga]: Universitas Kristen Satya Wacana; 2016.

36. Rahayu A, Purwoko T. Analisis Karbohidrat, Protein, dan Lemak pada Pembuatan Kecap Lamtoro Gung (Leucaena leucocephala) terfermentasi Aspergillus oryzae. Bioteknologi. 2005;2 (1), 14-20.

37. Kusnandar F, Budijanto S. Karakteristik Fungsional, Fisik dan Sensori Sereal Sarapan Jagung yang Disubstitusi Bekatul Fermentasi. Jurnal Aplikasi Teknologi Pangan. 2020;9(3):108-117.

38. Astuti AF, Wardani AK. Pengaruh Lama Fermentasi Kecap Ampas Tahu terhadap Kualitas Fisik, Kimia Dan Organoleptik. Jurnal Pangan dan Agroindustri 2016;4(1):72-83.

39. Steinkraus KH. Traditional food fermentations as industrial resources. Acta Biotechnol. 1983;3(1):3-12.

40. Yarmaliza Y. The Influence of Mother Characteristics on Giving Tempe Broth as an Effort Prevention of Stunting in Toddler. JKesmas. 2020;6(2):49-56.

41. Mursyid, Mursyid M, Jambi University, Wulansari D, Jambi University. Spiced Tempe Formulation and Evaluation of its Nutrition Values. Industria. 2018 Apr 13;7(1):57-65.

42. Hashim N, Woon Tai CWT, Xin Wen HXW, Ismail A, Kong KW. Comparative Evaluation of Antioxidant Properties and Isoflavones of Tempeh Fermented in Two Different Wrapping Materials. Curr Res Nutr Food Sci. 2018 Aug 28;6(2):307-17.

43. Keuth S, Bisping B. Vitamin B12 production by Citrobacter freundii or Klebsiella pneumoniae during tempeh fermentation and proof of enterotoxin absence by PCR. Applied and Environmental Microbiology. 1994;60(5):1495-9.

44. Muhiddin NH, Juli N. Peningkatan Kandungan Protein Kulit Umbi Ubi Kayu Melalui Proses Fermentasi. JMS. 2001;6(1):13.

45. Astuti M, Meliala A, Dalais FS, Wahlqvist ML. Tempe, a nutritious and healthy food from Indonesia. Asia Pac J Clin Nutr. 2000 Dec 29;9(4):322-5. 